\title{
Acclimatisation with lice-infested salmon improves cleaner fish lice consumption
}

\author{
Katharine Gentry ${ }^{1, *}$, Samantha Bui ${ }^{2}$, Frode Oppedal ${ }^{2}$, Reidun Bjelland ${ }^{3}$, \\ Velimir Nola ${ }^{2}$, Tim Dempster ${ }^{1}$
}

\author{
${ }^{1}$ Sustainable Aquaculture Laboratory - Temperate and Tropical (SALTT), School of BioSciences, University of Melbourne, \\ Victoria 3010, Australia \\ ${ }^{2}$ Institute of Marine Research, Matre Research Station, 5984 Matredal, Norway \\ ${ }^{3}$ Institute of Marine Research, Austevoll Research Station, 5392 Storebø, Norway
}

\begin{abstract}
Securing the welfare and maximising the lice removal efficacy of $\sim 60$ million cleaner fish used each year on salmonid farms is essential to develop a productive and ethical industry with low salmon lice Lepeophtheirus salmonis levels. We tested whether ballan wrasse Labrus bergylta welfare and lice consumption differed depending upon whether they were acclimatised in cages with either no Atlantic salmon Salmo salar, salmon without lice, or lice-infested salmon, prior to deployment in sea cages. After $1 \mathrm{wk}$, commercial densities of lice-infested salmon were stocked with the acclimatised wrasse in cages and kept for a further $3 \mathrm{wk}$. Each week, the number of lice on salmon was counted and a subset of wrasse was sampled for gut contents and physical welfare. Lice occurred less frequently in wrasse guts (6\% of all dietary items) compared to caprellid amphipods $(76 \%)$. Ballan wrasse consumed more lice if they were pre-exposed to lice-infested salmon (mean \pm $\mathrm{SE}=0.79 \pm 0.4$ lice $)$ compared to wrasse not pre-exposed to salmon $(0.15 \pm 0.1$ lice, $\mathrm{p}=0.003)$ or wrasse pre-exposed to salmon without lice $(0.01 \pm 0.09$ lice, $p=0.03)$. This did not affect overall mobile lice loads on salmon, which doubled over the study period regardless of acclimatisation strategy. Decline in condition factor $(K)$ and the increase in specific physical damage over time were not affected by acclimatisation strategy. If welfare can be secured, acclimatisation could be tested on cleaner fish at commercial scales as a strategy to improve biological control agents.
\end{abstract}

KEY WORDS: Aquaculture - Behaviour - Biological control $\cdot$ Lepeophtheirus salmonis · Parasite · Salmon lice

\section{INTRODUCTION}

Biological control is considered a sustainable solution to the rapid evolution of pesticide and medicinal resistance in pests (Bale et al. 2008). For this reason, Norwegian salmonid farms now stock $\sim 60$ million cleaner fish per year (rock cook wrasse Centrolabrus exoletus, goldsinny wrasse Ctenolabrus rupestris, ballan wrasse Labrus bergylta, corkwing wrasse Symphodus melops and lumpfish Cyclopterus lumpus) to control salmon lice Lepeophtheirus salmonis (hereafter lice) infestations (Overton et al. 2020). Lice are a serious welfare and economic problem for Atlantic salmon aquacul-

${ }^{*}$ Corresponding author: katharine.gentry@gmail.com ture (Olaussen 2018). The ectoparasites proliferate in the dense host populations of sea cages, reducing farm biomass and requiring costly chemical or mechanical treatments (Abolofia et al. 2017). Most lice that infest salmon in Norwegian farms are salmon lice, but Caligus elongatus is also present. From farms, salmon lice spill back to wild fishes and may reduce returning spawning populations in areas of salmon farming by 10-39 \% (Krkošek et al. 2013, Forseth et al. 2017).

As an alternative to chemical and mechanical control methods, $62.5 \%$ of Norwegian salmon farms stocked cleaner fish in 2019 (469 of 750 active sites: www.lusedata.no). Cleaner fish eat lice off salmon,

() The authors 2021. Open Access under Creative Commons by Attribution Licence. Use, distribution and reproduction are unrestricted. Authors and original publication must be credited. 
and small-scale trials indicate that they can keep lice levels at $<0.5$ lice salmon ${ }^{-1}$ (Skiftesvik et al. 2013, Leclercq et al. 2014a). However, many farms with cleaner fish still need to undertake regular chemical or mechanical treatments to remove lice (Overton et al. 2019). Research at commercial scale indicates that lumpfish can be effective in winter/ spring (Imsland et al. 2018), while wrasse performance is variable (Deady et al. 1995). Gut contents analyses show that $15-36 \%$ of lumpfish (Imsland et al. 2015) and $11 \%$ of corkwing wrasse (Gentry et al. 2020) consume lice, and lice feeding accounts for $\sim 0.2 \%$ of all behaviours observed (Imsland et al. 2014). A recent nation-scale analysis of 488 farms in Norway that completed a full production cycle between 2016 and 2018 concluded that while some sites achieved lice reduction results with cleaner fish, suboptimal use was widespread (Barrett et al. 2020).

For all species of cleaner fish, sea cage habitation is accompanied by high mortality (18-48\% over 6 mo; Nilsen et al. 2014; 60-100\% over the production period; Olsen 2017). This is likely due to infectious disease, handling, and predation, but moderate mortalities are often unreported, so the situation has not been thoroughly studied (Rimstad et al. 2017). Despite poor welfare (Nilsen et al. 2014, Rimstad et al. 2017) and inconsistent lice removal performance, cleaner fish use has increased 30-fold since 2009 (Norwegian Directorate of Fisheries 2020). Of the 49 million cleaner fish used on Norwegian salmon farms in 2018, 18 million were wild-captured (Norwegian Directorate of Fisheries 2020), with potential impacts on wild wrasse population structures (Halvorsen et al. 2017). The remaining 31 million fish (1 million ballan wrasse, 30 million lumpfish) used that year were cultured (Norwegian Directorate of Fisheries 2020). Given escalating use, there is substantial pressure on the industry to improve cleaner lice removal efficacy and welfare.

Acclimatisation of cleaner fish in small pens prior to stocking in full-scale sea cages could improve lice removal efficacy. Behaviours such as salmon inspection, lice identification, and lice removal need to be learned and practised for optimal prey handling efficiency (Warburton 2003). Bluegill sunfish Lepomis macrochirus and sea sticklebacks Spinachia spinachia typically require between 5 to 8 exposures to new prey before they reach peak prey handling efficiency (Werner et al. 1981, Hughes \& Mackney 1995). Although genetic and environmental factors can also contribute to variation in lice removal performance, approximately $20 \%$ more lumpfish eat lice after spending 3 mo in sea cages (Imsland et al. 2015), indicating that learning likely plays a pivotal role. Similarly, a national-scale data analysis of cleaner fish used from 2016 to 2018 at 488 Norwegian farms found that lice removal efficacy was best 2 to 4 mo after stocking (Barrett et al. 2020). Furthermore, while most corkwing wrasse in sea cages are unlikely to eat lice, $\sim 2 \%$ are 'super feeders' that eat lice almost exclusively (Deady et al. 1995, Gentry et al. 2020). It is possible that the majority of corkwing wrasse need encouragement - or a suitable learning environment - to initiate this behaviour. With fewer salmon present during acclimatisation, cleaner fish may be able to more rapidly identify salmon as nonthreatening with their low-density shoaling, and therefore initiate foraging and learning more quickly.

Increasingly, experts recommend that cleaner fish undergo an acclimatisation period to improve welfare in sea cages (Norwegian Seafood Research Fund 2018, Rabadan 2018). Acclimatisation makes transfer to sea cages with salmon less physiologically demanding for cleaner fish, whereby stress-induced immunosuppression, starvation, or mortalities are minimised (Barton \& Iwama 1991, Brooker et al. 2020). Previous acclimatisation strategies have involved adjustments to ambient seawater conditions and light cycles in tanks or small pens in the sea prior to stocking (Rabadan 2018, Brooker et al. 2020). Ballan wrasse acclimatised to natural conditions explored more of the net pen and swam higher in the water column than non-acclimatised fish (Leclercq et al. 2018, Brooker et al. 2020). Improved welfare may promote inspection behaviours and interactions with host fish.

Salmon are another novel aspect of the sea-cage environment to which cleaner fish must adjust. Deady et al. (1995) found that when wrasse were first introduced into cages, salmon behaved aggressively, injuring and/or eating the wrasse. By acclimating wrasse with low densities of salmon, cleaner fish may find and use hides and gradually habituate to salmon presence and behaviours, improving the transition to sea cages. We hypothesised that stocking salmon into small acclimatisation pens with cleaner fishes may improve subsequent welfare for cleaner fishes in sea cages.

Given that cleaner fish are the only vertebrates used as biological control agents in intensive animal production, there is a need to secure their welfare and maximise lice-feeding behaviours. Here, we investigated whether pre-exposing ballan wrasse to low numbers of lice-infested or lice-free salmon impacted their subsequent lice consumption or welfare in a sea-cage setting. 


\section{MATERIALS AND METHODS}

The experiment was conducted at the Institute of Marine Research's Austevoll Research Station $\left(\sim 60^{\circ} \mathrm{N}\right)$ using the sea-cage facilities at Sauganeset from June to July 2018. This study adhered to the Norwegian Regulations for Animal Experimentation (animal ethics permit ID 15509).

\subsection{Research animals}

One-year-old ballan wrasse $(\mathrm{n}=249$, weight: range $=15-60 \mathrm{~g}$, mean $=27.6 \mathrm{~g}$; length: range $=$ $9.9-15 \mathrm{~cm}$, mean $=11.6 \mathrm{~cm}$ ) bred from multiple wildcaught broodstock and cultured in tanks at Austevoll Research Station under standard husbandry methods were used in this experiment. Prior to transfer to sea cages, they were held in one $1500 \mathrm{l}$ tank under diurnal conditions without hides. The Atlantic salmon (Aquagen strain, $\mathrm{n}=4200$, mean $\pm \mathrm{SE}$ weight and length $190.0 \pm 6.8 \mathrm{~g}$ and $26.2 \pm 0.31 \mathrm{~cm}$, respectively) were transferred to experimental sea cages from a stocking cage where they had been held for 3 mo prior with standard husbandry procedures.

\subsection{Experimental set-up}

We conducted an experiment to test whether acclimation strategy improved lice consumption and welfare of ballan wrasse stocked into sea cages. The experiment was not explicitly designed to test whether cleaner fish are effective at reducing lice numbers in sea cages, which would have required comparison to cages with no cleaner fish (see Overton et al. 2020). Three acclimatisation strategies were tested: (1) exposure to small groups of salmon without lice, (2) exposure to lice-infested salmon, and (3) no exposure to salmon, where wrasse were held in the acclimatisation cage alone.

To minimise any effects of cage position within the fish farm, acclimatisation strategies were allocated to sea cages ( 3 replicates per treatment, $\mathrm{N}=9$ ) in a randomised block design (Fig. 1). During the acclimatisation week, sea-cage nets were pulled up to a configuration of $5 \times 5 \times 1 \mathrm{~m}$. After the acclimatisation week, the same nets were released to their full depth of $5 \mathrm{~m}$.

Throughout the study period, each sea cage contained $1 \times 4 \mathrm{~m}$ artificial kelp hide suspended from the southwest corner, at least $90 \mathrm{~cm}$ from the net wall. Twice a week, ballan wrasse were fed the same feed as they were given in the tanks prior to stocking
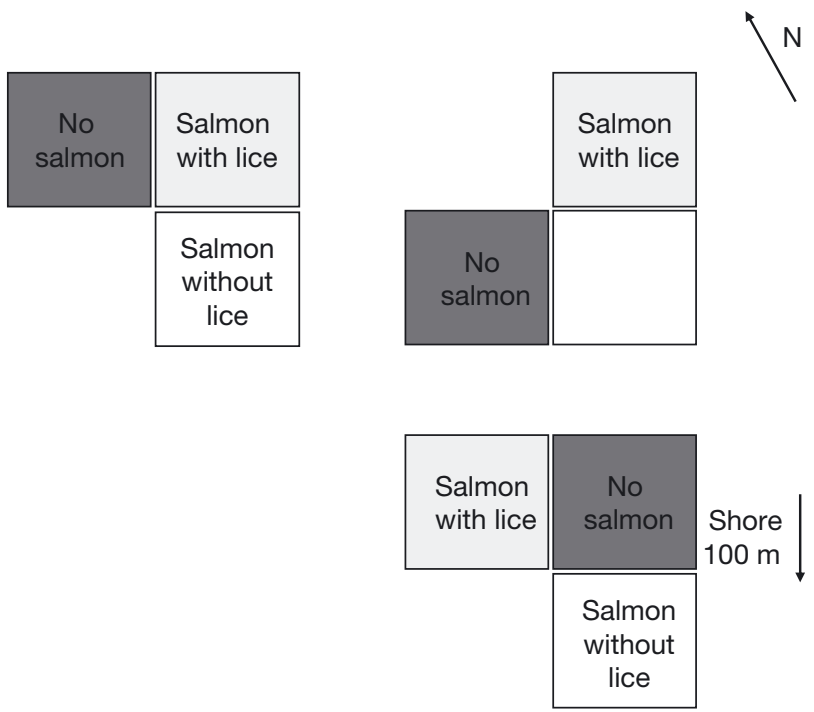

Fig. 1. Bird's eye, diagrammatic representation of the seacage arrangement at the research facility. Each square represents a $5 \times 5 \mathrm{~m}$ sea cage. Acclimatisation strategies, indicated in each cage, were allocated to sea cages in a randomised block design. Current flowed generally in a southwesterly direction through the cage facility

(Skretting $12 \mathrm{~mm}$ Clean Soft blended with prawns and seawater, $100 \mathrm{~g}$ in a mesh feed sock positioned $2 \mathrm{~m}$ deep, $<30 \mathrm{~cm}$ from hide), and salmon were fed daily (Skretting, $4.5 \mathrm{~mm}$, Spirit Supreme, delivered by automatic feeder) to satiation. Between 13:00 and 15:00 h each day, measurements of temperature, oxygen, and conductivity at 0.5 and $5 \mathrm{~m}$ depth were recorded using a YSI Pro30 Handheld Conductivity Meter.

\subsection{Experimental design}

On 1 June 2018 ('Sample Time 0'; Day -9), ballan wrasse were hand-netted from the tank and transferred to a bucket with immersion sedation (Finquel, tricaine methanesulfonate, $0.1 \mathrm{~g} \mathrm{l}^{-1}$ ). Length $(\mathrm{cm})$ from snout to caudal fin and mass $(\mathrm{g})$ were measured, from which Fulton's condition factor $\left(K=W /(L)^{3} \times\right.$ 100) was calculated to estimate condition. Pectoral fins, caudal fin, dorsal fin, skin, snout, eye, and opercula damage were recorded as present (scars and past damage included) or absent (no old or new damage evident), as were deformities (see Table $\mathrm{S} 1$ in the Supplement at www.int-res.com/articles/suppl/q013 p041_supp.pdf). Ballan wrasse were then transferred to a recovery bucket, then to sea cages.

On 4 June ('Sample Time 0'; Day -7), salmon were transferred to the appropriate cage replicates and the acclimatisation period began. The 3 acclimatisa- 
tion strategies were: (1) 30 ballan wrasse, no salmon; (2) 30 ballan wrasse, 100 manually deloused salmon ( $\mathrm{N}=300,30 \%$ cleaner fish stocking density); and (3) 30 ballan wrasse, 100 salmon ( $\mathrm{N}=300,30 \%$ cleaner fish stocking density) with 1 to 8 (mean $=4.0 \pm 0.6$ ) mobile lice salmon ${ }^{-1}$. Lice numbers were determined from 20 salmon collected during the transfer. Cleaner wrasse only prey upon mobile (preadult, adult male, and adult female) stages of Lepeophtheirus salmonis and Caligus elongatus (Brooker at al. 2018). One week later (11 June; Day 0), while minimising disturbance to the wrasse, all salmon were removed with a dip net. Then, 400 new salmon $(\mathrm{N}=3600)$ with 1 to 18 mobile lice per fish (mean $=4.6 \pm 0.2$ ) were added to each cage (cleaner fish stocking number to salmon = $7.5 \%$; Day 0).

On 18 June ('Sample Time 1'), 25 June ('Sample Time 2'), and 2 July ('Sample Time 3'), the net floor for each cage was raised and 8 (Sample Times 1 and 2) or 14 (Sample Time 3) ballan wrasse were netted out and euthanised with an overdose of immersion sedation (Finquel, tricaine methanesulfonate, $0.3 \mathrm{~g} \mathrm{l}^{-1}$ ). This reduced the cleaner fish:salmon ratio between sampling times from $7.5 \%$ (Sample Time 1) to $5.8 \%$ (Sample Time 2) and $\sim 3.9 \%$ (Sample Time 3). Cages were sampled sequentially in a randomised order between 09:00 and 11:00 h. As the experiment occurred in June and July where there is $18-20 \mathrm{~h}$ of daylight, plus twilight, fish sampled at 09:00-11:00 h had 6-8 $\mathrm{h}$ of light to consume prey in the morning before sampling. Ballan wrasse were also fed supplementary feed the day after and $2 \mathrm{~d}$ before sampling.

The physical welfare of ballan wrasse was scored by the same person using the same methods as in Sample Time 0. Each wrasse was dissected for visual analysis of gut contents. Although lice can begin to breakdown during digestion, their bodies are usually intact, round, pink, and easily distinguishable from other digested items, including the elongated and orange caprellid amphipods. Individual prey items were counted and identified to the lowest taxonomic level possible, then the entire contents of the digestive tract were scooped into a measuring cylinder to measure gut content volume. When prey items were extremely digested and unidentifiable using microscopes, they were marked as 'unknown'. Gut inspection took place within $1 \mathrm{~h}$ of catching wrasse.

At each sampling time, 20 salmon from each cage were captured with a dip net and anaesthetised (Finquel, tricaine methanesulfonate, $0.1 \mathrm{~g} \mathrm{l}^{-1}$ ), and all lice stages that were present on individual salmon were recorded, including lice that fell off in the sedation tub. Salmon were transferred afterwards to a non- experimental cage for recovery and on-growth and were no longer used in the study.

\subsection{Statistical analyses}

To test whether ballan wrasse lice consumption differed between acclimatisation strategies or over time, count data of lice found in guts were $(\log +1)$ transformed to fit a Poisson distribution and then analysed using a generalised linear mixed-effects model estimated by maximum likelihood (function glmmTMB in package 'glmmTMB', RStudio v.3.4.2; RStudio Team 2018). Wrasse gut volume was standardised using log-transformed fish mass $\left(\mathrm{ml} \mathrm{g}^{-1}\right)$ and analysed using a linear mixed-effects model (function lmer in 'Ime4'). For these models, and all models in this study, group and time were treated as fixed effects, while cage was treated as a random effect.

To test whether acclimatisation strategy impacted the number of mobile lice salmon ${ }^{-1}$, data were fitted to a negative binomial distribution (Shaw \& Dobson 1995) and analysed using a generalised linear mixed model estimated by maximum likelihood (function glmmTMB in package 'glmmTMB'). Given that the industry uses the number of adult female lice salmon $^{-1}$ as a cue to mechanically or chemically delouse (e.g. Norwegian Ministry of Trade Industry and Fisheries 2012), another model was run analysing only abundance of adult female lice salmon ${ }^{-1}$.

To determine whether physical welfare of wrasse differed between acclimatisation strategies, the $K$ score and the percent of fish with damage of a body part fitted a normal distribution ( $K$-score) or were arcsin squareroot transformed to fit a normal distribution (left and right pectoral fins, dorsal fin, caudal fin, skin, and snout). Each body part and $K$-score was analysed using a linear mixed-effects model estimated by maximum likelihood (function lmer in 'Ime4'). Homogeneity of variance and normality of errors were confirmed by inspecting residual plots. Opercula and eye damage were not analysed as their frequency of occurrence was negligible $(<2$ across all samples).

All models were compared to corresponding null models, excluding group and then time as a factor in likelihood ratio tests (function anova). For linear mixed-effects models where $\mathrm{p}<0.05$, post hoc analyses (function lsmeans in 'lsmeans') generated adjusted p-values. For generalised linear mixed-effects models where $\mathrm{p}<0.05$, data were analysed within time points to determine differences between individual groups (function anova). 


\section{RESULTS}

\subsection{Environmental conditions}

Sea temperature $\left(0.5 \mathrm{~m}\right.$ : range $=11.4-18.4^{\circ} \mathrm{C}$, mean $=14.9^{\circ} \mathrm{C} ; 5 \mathrm{~m}$ : range $=9.6^{\circ} \mathrm{C}-17.1$, mean $=13.4^{\circ} \mathrm{C}$ ) was highest at the beginning of the experiment, causing the sharpest thermocline of up to $4.7^{\circ} \mathrm{C}$ difference from 0.5 to $5 \mathrm{~m}$ depth (Fig. S1A). Excluding this first week, the temperature difference between the surface and $5 \mathrm{~m}$ depth was $\sim 1^{\circ} \mathrm{C}$. Salinity did not vary widely during the experimental period $(0.5 \mathrm{~m}$ : range $=27.1-30.7 \mathrm{PSU}$, mean $=28.9 \mathrm{PSU} ; 5 \mathrm{~m}$ : range $=28.0-$ 31.7 PSU, mean $=29.6$ PSU; Fig. S1B). Dissolved oxygen content remained above $90 \%$ saturation throughout the experiment for both 0.5 and $5 \mathrm{~m}$ depth.

\subsection{Lice consumed by ballan wrasse}

Ballan wrasse pre-exposed to lice-infested salmon consumed significantly more lice $(n=102$ lice in

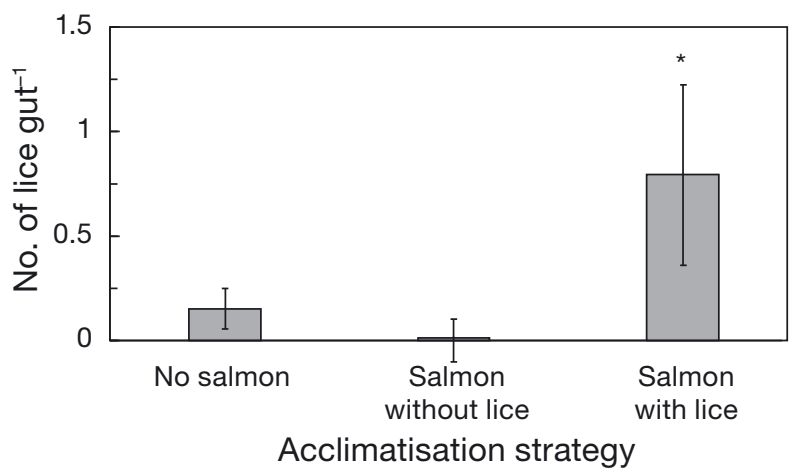

Fig. 2. Number of salmon lice per ballan wrasse gut (mean \pm $\mathrm{SE})$ for each acclimatisation strategy across sample times wrasse stomachs, mean $=0.79 \pm 0.4$ ) than wrasse preexposed to non-infested salmon alone $(\mathrm{n}=79$, mean $=$ $\left.0.01 \pm 0.09, \chi^{2}=12.9, \mathrm{p}=0.003\right)$ and wrasse without exposure to salmon $\left(\mathrm{n}=68\right.$, mean $=0.15 \pm 0.1, \chi^{2}=$ $4.4, p=0.03$; Fig. 2). Sample time did not affect the number of lice found in ballan wrasse stomachs $\left(\chi^{2}=\right.$ $0.6, p=0.7$ ). Only pre-adult and adult lice stages of both sexes were found in wrasse guts. In line with the results on abundance, lice were more frequent in stomachs of wrasse pre-exposed to lice-infested salmon than the other treatments (Table S2).

\subsection{Lice on salmon}

Acclimatisation strategy did not affect the number of mobile $\left(\chi^{2}=5.3, p=0.07\right.$; Fig. 3$)$ or adult female lice stages on salmon $\left(\chi^{2}=0.6, p=0.7\right)$. There were more mobile lice stages on salmon at Sample Time 3 (mean $=5.1 \pm 0.39$ ) compared to Sample Times 0 (mean $=3.1 \pm 0.39, \mathrm{p}<0.0001), 1($ mean $=4.4 \pm 0.23, \mathrm{p}=0.04)$, and 2 (mean $=3.4 \pm 0.14, \mathrm{p}<0.0001)$. Adult female lice stages were more common at Sample Time 2 (mean = $0.8 \pm 0.1$ ) compared to Sample Times 0 (mean $=0.5 \pm$ $0.1, \mathrm{p}=0.02)$ and $1($ mean $=0.4 \pm 0.06, \mathrm{p}<0.001)$. There were no other differences in lice on salmon across time.

\subsection{Physical welfare}

Ballan wrasse condition ( $K$-factor) was not affected by acclimatisation strategy $\left(\chi^{2}=3.5, \mathrm{p}=0.2\right)$, but decreased over time in sea cages $\left(\chi^{2}=34, \mathrm{p}<0.001\right.$; Fig. 4). Post hoc analyses revealed that condition prior to acclimatisation (mean $=1.75 \pm 0.02$ ) was higher than all other sample times (Sample Time 1:

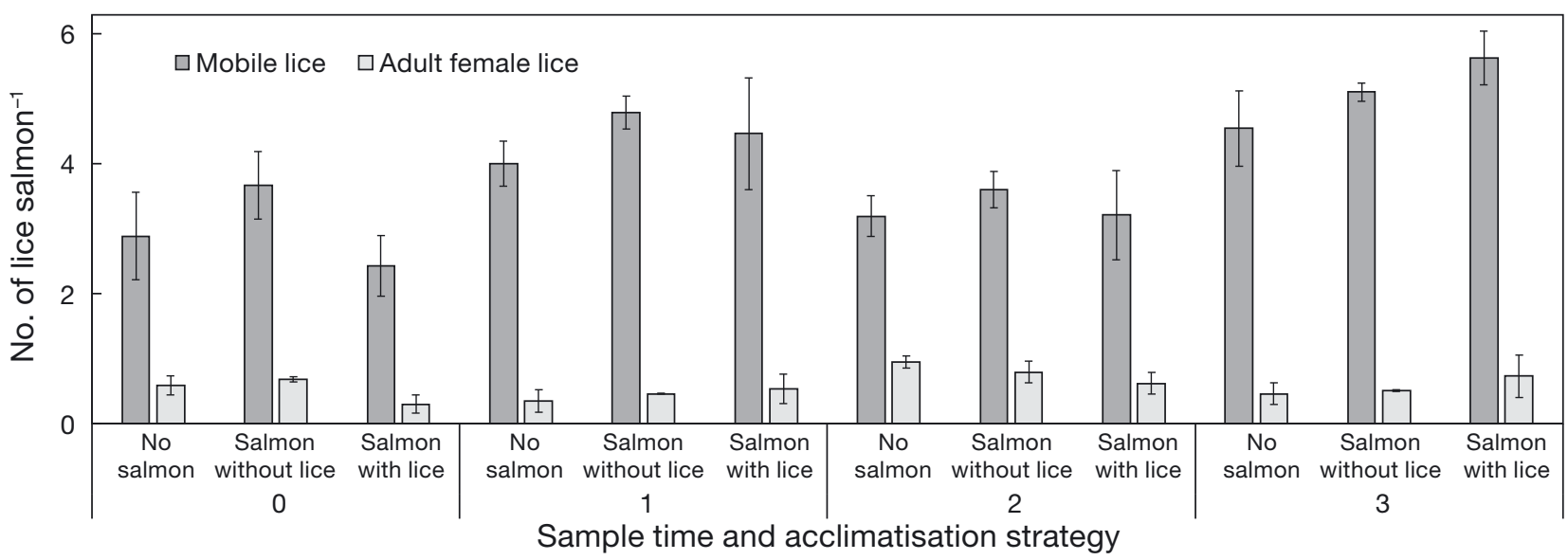

Fig. 3. Number of mobile and adult female salmon lice stages (mean \pm SE) on salmon in sea cages with cleaner fish that have been acclimatised to no salmon, salmon, or lice-infested salmon at Sample Times 0, 1, 2, and 3 


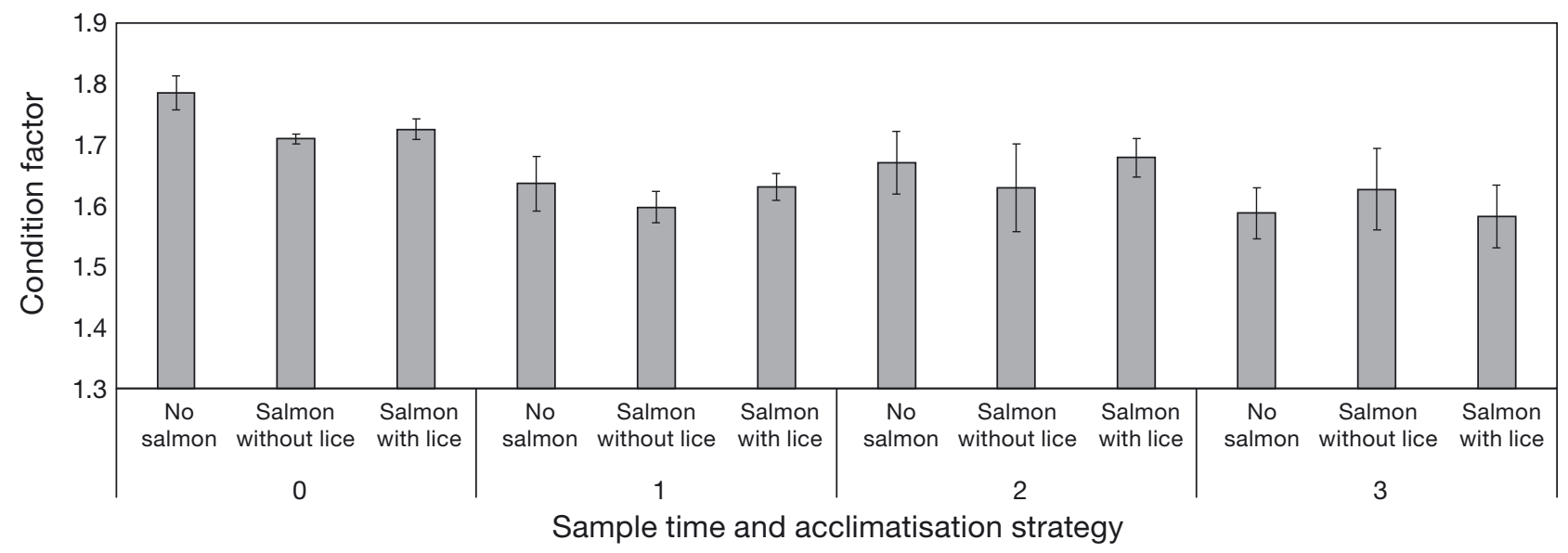

Fig. 4. Ballan wrasse condition factor (mean $\pm \mathrm{SE}$ ) for each acclimatisation strategy at Sample Times 0, 1, 2, and 3

mean $=1.62 \pm 0.03, \mathrm{p}<0.001 ;$ Sample Time 2: mean $=$ $1.66 \pm 0.05, \mathrm{p}=0.04 ;$ Sample Time 3: mean $=1.59 \pm$ $0.05, \mathrm{p}<0.001$ ). Condition declined by $9 \%$ from prior to acclimation to sample Time 3.

Acclimatisation strategy generally did not affect the percentage of wrasse with fin damage (right pectoral: $\chi^{2}=3.1, \mathrm{p}=0.21$; left pectoral $\chi^{2}=5.5, \mathrm{p}=$ 0.06; caudal: $\chi^{2}=1.5, \mathrm{p}=0.46$; Table S3). However, more ballan wrasse pre-exposed to lice-infested salmon had dorsal fin damage $(n=29)$ than wrasse without exposure to lice ( $\mathrm{n}=13$ in the group unexposed to salmon, $\mathrm{n}=12$ in the group exposed to salmon without lice) ( $p=0.04$; Fig. 5). Additionally,

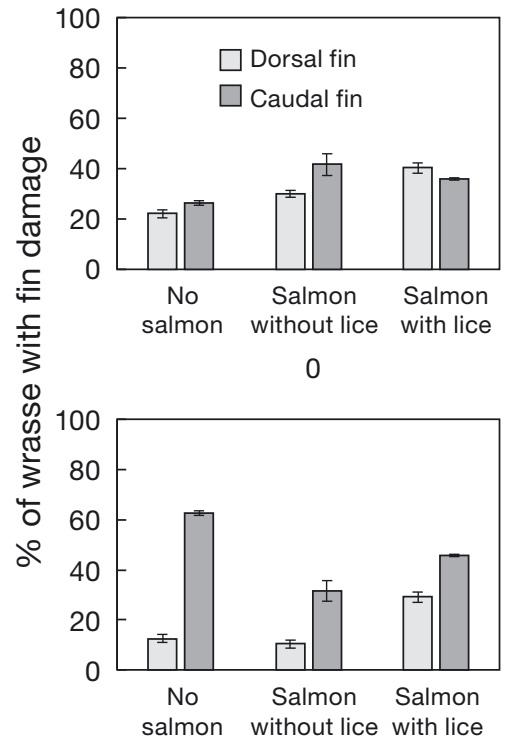

2

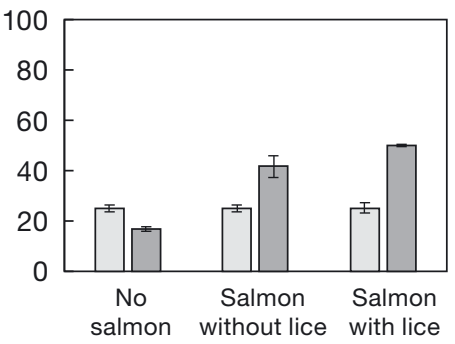

1

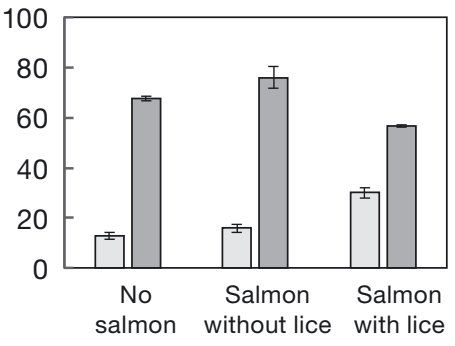

3
Sample time and acclimatisation strategy

Fig. 5. Percentage of ballan wrasse with caudal and dorsal fin damage (mean $\pm \mathrm{SE}$ ) for each acclimatisation strategy Sample Times 0, 1, 2, and 3
1.4-1.9 times more wrasse had damaged caudal fins at Sample Time 3 (mean $=67 \pm 3.8 \%$ ) compared to Sample Time $0($ mean $=35 \% \pm 1.8, \mathrm{p}=0.005)$ and Sample Time 1 (mean $=36 \pm 2.8 \%, p=0.007)$. Left pectoral fin damage $($ mean $=82 \% \pm 3.6$ ) was $\sim 1.2$ times more common than right pectoral fin damage $($ mean $=70 \pm 4.4 \%)$ across sample times $\left(\chi^{2}=31.3\right.$, $\mathrm{p}<0.001)$.

Skin $(\mathrm{n}=40)$ and snout $(\mathrm{n}=8)$ damage were not affected by acclimatisation strategy (skin: $\chi^{2}=0.48$, $\mathrm{p}=0.79$; snout: $\chi^{2}=3.4, \mathrm{p}=0.19$ ) or time (skin: $\chi^{2}=$ $0.59, \mathrm{p}=0.90$; snout: $\chi^{2}=5.8, \mathrm{p}=0.12$ ). No ballan wrasse mortalities were observed, and a total of 17 salmon mortalities occurred over the experimental period. Salmon mortality did not vary across treatments.

\subsection{Gut contents}

The predominant prey items in ballan wrasse guts were caprellid amphipods (occurring in $76 \%$ of wrasse stomachs), followed by lice $(6 \%)$, molluscs $(2 \%)$, other fish $(2 \%)$, algae $(2 \%)$, and other unidentifiable items (3\%) (Table S2). A small proportion of sampled wrasse had empty stomachs (10\%; Fig. S2). Gut contents did not differ between treatments, but post hoc pairwise comparisons revealed that ballan wrasse had a larger volume of food in their guts (mean $\pm \mathrm{SE}=$ $1.5 \pm 0.09 \mathrm{ml}$; Fig. S2) in Sample Time 3 compared to Sample Times 1 (0.5 \pm $0.09 \mathrm{ml}, \mathrm{p}<0.0001)$ and $2(0.7 \pm 0.3 \mathrm{ml}$, $\mathrm{p}<0.0001)$. 


\section{DISCUSSION}

We tested whether different 1 wk acclimatisation strategies affect ballan wrasse lice consumption and welfare within the first $3 \mathrm{wk}$ of sea cage habitation with high stocking densities of salmon. Under these conditions, ballan wrasse acclimatised with liceinfested salmon are more likely to consume lice than individuals with no prior experience of salmon or lice. Although this sheds light on a potential strategy to improve cleaner fish efficacy on salmon farms, higher levels of lice found in their stomachs did not translate to lower lice loads on salmon or improved welfare of ballan wrasse during the experiment.

\subsection{Acclimatisation strategy}

\subsubsection{Effect on lice consumption}

The likely mechanism behind greater lice consumption by lice-acclimatised wrasse is learning. Lice-acclimatised wrasse had more opportunities to practise lice-feeding behaviours and optimise preyhandling. Therefore, to effectively lower lice loads on salmon, the wrasse may have required even more opportunities to interact with lice (i.e. more lice per salmon). This could explain why studies that find ballan wrasse effectively control lice have very high initial lice loads on salmon (e.g. $~ 6$ adult lice salmon ${ }^{-1}$ in small-scale sea cages [Skiftesvik et al. 2013], 12 lice salmon $^{-1}$ in tanks [Leclercq et al. 2014a]). The wrasse in these studies continued to be effective once lice loads were reduced to typical commercial levels. However, neither of these studies explored the possibility that wrasse lice consumption is impacted by what other prey is available. Previous research indicates that supplementary feed does not affect delousing efficacy (Leclercq et al. 2014a), but the high occurrence of caprellid amphipods in the guts of our wrasse suggests that preferential feeding of other prey items may be a barrier to improved lice consumption. Further work investigating lice consumption in different contexts is required.

If, as our results suggest, learning is imperative to encouraging development of lice-feeding behaviours, then opportunities to become excellent delousers are restricted in typical sea cages. Salmon held in commercial cages are chemically or mechanically treated before carrying the legislated legal limit of 0.5 adult female lice per fish (or 0.2 adult female lice per fish during spring) - less than the 0.6 adult female lice per fish in our study. Thus, cleaner fish rarely experience the large amounts of lice on salmon that were reported by Leclercq et al. (2014a) and Skiftesvik et al. (2013) in their small-scale acclimatisation studies. While acclimatisation in net pens may be restricted by regulated lice limits, further refinements of this acclimatisation strategy may find that only a few salmon with heavy lice loads are required in smaller or closed acclimatisation pens. In addition, cleaner fish may learn lice-eating behaviours from 'expert' individuals that have prior experience with salmon and lice. If peer-learning is successful, both video footage and models can elicit behavioural responses in fish (Rowland 1999, Ingley et al. 2015), so cleaners could even learn lice-eating behaviours without live fish.

\subsubsection{Effect on physical welfare}

Inhabiting sea cages reduced the ballan wrasse $K$ factor by $10 \%$ and increased caudal fin damage, and acclimatisation strategies did not improve outcomes. Skin, pectoral fin, dorsal fin, and snout damage did not increase with time in sea cages. Thus, it is likely that an inherent part of the sea cage (e.g. the lack of solid surfaces for wrasse to rest on, the unenriched habitat, changed food availability) causes wrasse to deteriorate in body condition. Only $10 \%$ of wrasse had empty guts, but it is still possible that they did not eat enough food between sampling times. Notably, no individuals had supplementary feed in their guts. This was unexpected, as the wrasse were familiar with the supplementary feed provided, having been raised on it prior to the experiment. The amount of food in guts had increased by Sample Time 3, so ballan wrasse may have been adapting to the cage environment, and condition factor could plateau or improve with more time. For hatchery-reared wrasse, the very high $K$ (e.g. 1.75 in the present study) may provide a buffer while wrasse adapt and learn to feed in sea-cage conditions. Future studies are required to test if cleaner fish condition deteriorates over time at a commercially relevant scale.

Dorsal fin damage was more common in the wrasse group acclimatised with lice-infested salmon compared to the wrasse with no pre-exposure to salmon. Salmon inspection behaviours draw ballan wrasse into proximity of salmon, so this damage may be caused by longer exposure to and more interactions with salmon. Caudal fin damage was more widespread in all groups as the study continued. This may be caused by intraspecific or interspecific aggression or contact with the net or hide. It is unlikely to have 
been caused by sampling procedures, as these were the same each week. If caudal fins were damaged due to interspecific interactions or contact with seacage structures, improving hides (e.g. providing solid surfaces for resting; hiding places inaccessible to salmon) may reduce caudal fin damage.

Overall, it is still uncertain what the primary stressor in the sea-cage environment is for ballan wrasse. It may be the large group of salmon, the greater area to explore, the net or cage structure itself, inadequate shelter from environmental conditions, or a combination of these factors. While understanding of the acute stress response of ballan wrasse is increasing (e.g. Leclercq et al. 2014b), there is a need for further studies investigating factors that optimise ballan wrasse welfare that can be applied during acclimatisation or sea-cage habitation. The swimming capabilities of cultured wrasse have been recently documented (Yuen et al. 2019), but basic physiological studies to define stress levels and coping abilities are needed.

\subsection{Industry applications}

There may be challenges applying acclimatisation at an industry scale. First, the 5 species of cleaner fish may each respond differently to acclimatisation strategies. For wild-caught cleaners, acclimatisation would occur at the salmon farm. Sea cages or custom-built acclimatisation pens would have to be maintained and set aside for cleaner fish, and transferring fish between pens may stress stock and extend work hours. Ocean acclimatisation may prove more successful in countries where lice loads are higher. Mandated lice intervention limits vary from country to country, with Scotland and Canada allowing more adult female lice per farmed salmon than Norway and Ireland (Scotland: 6 adult female lice fish $^{-1}$ [Marine Scotland 2019]; Canada: 3 mobile lice fish $^{-1}$ [Fisheries and Oceans Canada 2020]; Norway: 0.5 adult female salmon lice fish ${ }^{-1}$, or $0.2 \mathrm{fish}^{-1}$ during wild salmon outmigration [Norwegian Ministry of Trade Industry and Fisheries 2012]; Ireland: 0.5 ovigerous adult female lice fish $^{-1}$ [Marine Institute 2020]).

Widespread acclimatisation of cleaner fish would be most feasible for farmed ballan wrasse and lumpfish within hatcheries. Twenty-six million cleaner fish per year are produced in hatcheries (Norwegian Directorate of Fisheries 2020), which could acclimatise large batches of tens or hundreds of thousands of cleaner fish in tanks. However, transportation to farms in well boats or trucks may undermine the pos- itive effects of acclimatisation. In addition, hatcheries have strict biosecurity regulations, and stocking liceinfected salmon with cleaner fish may enhance disease risk. It is important that acclimatisation is tested at progressively larger scales across all species, to confirm that it works on commercial farms. Further, strategies such as hide improvement, periodic confinement from salmon, creation of designated 'cleaning stations', development of species-specific operational welfare indicators, and habitat enrichment may improve cleaner fish welfare and must be explored. If acclimatisation can consistently produce effective, hardy wrasses and lumpfish, benefits may compensate for the risks.

By modifying the simple, widespread process of acclimatisation, this study may help aquaculture managers develop effective lice management strategies. As the demand for 'green' lice control technologies that use no chemicals and have limited welfare effects on salmon increases (Hersoug 2015), the farming industry will come under increasing scrutiny to secure the welfare of the $>60$ million vertebrates used for biological control. Ultimately, if lice-feeding behaviour and cleaner fish welfare can be improved, the number of cleaner fish required in sea cages may be reduced.

Acknowledgements. We thank staff at IMR's Austevoll fish farm for technical support during field sampling, including Bjørn-Magne Hufthammar, Jan Erik Fosseidengen, Anne Berit Skiftesvik, Tina Oldham, Chris Oldham, Ida Berge Waage, Florian Freytet, Rosa Escobar, and Andreas Habbestad Andersen. Funding was provided by the Institute of Marine Research and the University of Melbourne.

\section{LITERATURE CITED}

Abolofia J, Asche F, Wilen JE (2017) The cost of lice: quantifying the impacts of parasitic sea lice on farmed salmon. Mar Resour Econ 32:329-349

* Bale JS, Van Lenteren JC, Bigler F (2008) Biological control and sustainable food production. Philos Trans R Soc B 363:761-776

Barrett LT, Overton K, Stien LH, Oppedal F, Dempster T (2020) Effect of cleaner fish on sea lice in Norwegian salmon aquaculture: a national-scale data analysis. Int J Parasitol 50:787-796

* Barton BA, Iwama GK (1991) Physiological changes in fish from stress in aquaculture with emphasis on the response and effects of corticosteroids. Annu Rev Fish Dis 1:3-26

* Brooker AJ, Papadopoulou A, Gutiérrez C, Rey S, Davie A, Migaud H (2018) Sustainable production and use of cleaner fish for the biological control of sea lice: recent advances and current challenges. Vet Rec 183:383

Brooker AJ, Davie A, Leclercq E, Zerafa B, Migaud H (2020) Pre-deployment acclimatisation of farmed ballan wrasse (Labrus bergylta) to sea-cage conditions promotes be- 
haviour analogous to wild conspecifics when used as cleaner fish in Atlantic salmon (Salmo salar) farms. Aquaculture 520:734771

Neady S, Varian SJA, Fives JM (1995) The use of cleanerfish to control sea lice on two Irish salmon (Salmo salar) farms with particular reference to wrasse behaviour in salmon cages. Aquaculture 131:73-90

Fisheries and Oceans Canada (2020) Marine finfish BC aquaculture licence and conditions of licence. https://www. pac.dfo-mpo.gc.ca/aquaculture/licence-permis/docs/ licence-cond-permis-mar/index-eng.html\#6 (accessed 14.10.2020)

Forseth T, Barlaup BT, Finstad B, Fiske P and others (2017) The major threats to Atlantic salmon in Norway. ICES J Mar Sci 74:1496-1513

* Gentry K, Bui S, Oppedal F, Dempster T (2020) Sea lice prevention strategies affect cleaner fish delousing efficacy in commercial Atlantic salmon sea-cages. Aquacult Environ Interact 12:67-80

* Halvorsen KT, Larsen T, Sørdalen TK, Vøllestad LA, Knutsen H, Olsen EM (2017) Impact of harvesting cleaner fish for salmonid aquaculture assessed from replicated coastal marine protected areas. Mar Biol Res 13:359-369

Hersoug B (2015) The greening of Norwegian salmon production. Marit Stud 14:1-19

Hughes RN, Mackney PA (1995) Foraging behaviour and memory window in sticklebacks. Behaviour 132:1241-1253

Imsland AK, Reynolds P, Eliassen G, Hangstad TA and others (2014) Notes on the behaviour of lumpfish in sea pens with and without Atlantic salmon present. J Ethol 32: $117-122$

Imsland AK, Reynolds P, Eliassen G, Hangstad TA and others (2015) Feeding preferences of lumpfish (Cyclopterus lumpus) maintained in open net-pens with Atlantic salmon (Salmo salar). Aquaculture 436:47-51

Imsland AKD, Hanssen A, Nytrø AV, Reynolds P and others (2018) It works! Lumpfish can significantly lower sea lice infestation in large-scale salmon farming. Biol Open 7: bio036301

Ingley S, Asl M, Wu C, Cui R and others (2015) anyFish 2.0: An open-source software platform to generate and share animated fish models to study behavior. SoftwareX 3-4: 13-31

Krkošek M, Revie CW, Gargan PG, Skilbrei OT, Finstad B, Todd CD (2013) Impact of parasites on salmon recruitment in the Northeast Atlantic Ocean. Proc R Soc B 280: 20122359

Leclercq E, Davie A, Migaud H (2014a) Delousing efficiency of farmed ballan wrasse (Labrus bergylta) against Lepeophtheirus salmonis infecting Atlantic salmon (Salmo salar) post-smolts. Pest Manag Sci 70:1274-1282

Leclercq E, Davie A, Migaud H (2014b) The physiological response of farmed ballan wrasse (Labrus bergylta) exposed to an acute stressor. Aquaculture 434:1-4

Leclercq E, Zerafa B, Brooker A, Davie A, Migaud H (2018) Application of passive-acoustic telemetry to explore the behaviour of ballan wrasse (Labrus bergylta) and lumpfish (Cyclopterus lumpus) in commercial Scottish salmon sea-pens. Aquaculture 495:1-12

Marine Institute (2020) Sea lice. www.marine.ie/Home/ site-area/areas-activity/aquaculture/sea-lice (accessed 14.10.2020)

Marine Scotland (2019) The regulation of sea lice in Scotland. www.gov.scot/binaries/content/documents/govscot/ publications/factsheet/2019/11/marine-scotland-topicsheets-aquaculture/documents/the-regulation-of-sealice-in-scotland-updated-june-2019/the-regulation-of- sea-lice-in-scotland-updated-june-2019/govscot $\% 3 \mathrm{~A}$ document/regulation-sea-lice.pdf

Nilsen A, Viljugrein H, Røsæg M, Colquhoun D (2014) Rensefiskhelse - kartlegging av dødelighet og dødelighetsårsaker. Veterinærinstituttets rapportserie 12-2014. Veterinærinstituttet, Oslo

Norwegian Directorate of Fisheries (2020) Cleaner Fish (lumpfish and wrasse) Statistics Norway. www.fiskeridir. no/content/download/7623/95528/version/53/file/stalaks-mat-10-rensefisk.xlsx

Norwegian Ministry of Trade Industry and Fisheries (2012) Regulation on salmon lice control in aquaculture facilities, FOR-2012-12-05-1140 (In Norwegian). https:// lovdata.no/dokument/SF/forskrift/2012-12-05-1140 (accessed 14.10.2020)

Norwegian Seafood Research Fund (2018) FHF cleaner fish guidelines (in English). https://www.scottishaquaculture. com/media/1470/fhf-cleanerfish-guidelines.pdf

Olaussen JO (2018) Environmental problems and regulation in the aquaculture industry. Insights from Norway. Mar Policy 98:158-163

* Olsen S (2017) Næringen trenger ikke enda flere å spise wienerbrød med, de trenger rett og slett også litt tyggemotstand. https://ilaks.no/naeringen-trenger-ikke-endaflere-a-spise-wienerbrod-med-de-trenger-rett-og-slettogsa-litt-tyggemotstand/ (accessed 14/10/2020)

* Overton K, Dempster T, Oppedal F, Kristiansen T, Gismervik K, Stien L (2019) Salmon lice treatments and salmon mortality in Norwegian aquaculture: a review. Rev Aquacult 11:1398-1417

* Overton K, Barrett LT, Oppedal F, Kristiansen T, Dempster T (2020) Sea lice removal by cleaner fish in salmon aquaculture: a review of the evidence base. Aquacult Environ Interact 12:31-44

RStudio Team (2018) R: a language and environment for statistical computing. R Foundation for Statistical Computing, Vienna

Rabadan CG (2018) Improving the use of wrasse (Labridae) stocked in commercial sea cages with Atlantic salmon (Salmo salar) for sea lice control: key features for a successful deployment. In: Treasurer J (ed) Cleaner fish biology and aquaculture applications. 5m Publishing, p 54-68

Rimstad E, Basic D, Gulla S, Hjeltnes B, Mortensen S (2017) Risk assessment of fish health associated with the use of cleaner fish in aquaculture. Opinion of the Panel on Animal Health and Welfare of the Norwegian Scientific Committee for Food and Environment. VKM report 2017:32. Norwegian Scientific Committee for Food and Environment (VKM), Oslo

Rowland WJ (1999) Studying visual cues in fish behaviour: a review of ethological techniques. Environ Biol Fishes 56: 285-305

Shaw DJ, Dobson AP(1995) Patterns of macroparasite abundance and aggregation in wildlife populations: a quantitative review. Parasitology 111 (Supp S1):S111-S133

* Skiftesvik AB, Bjelland RM, Durif CMF, Johansen IS, Browman HI (2013) Delousing of Atlantic salmon (Salmo salar) by cultured vs. wild ballan wrasse (Labrus bergylta). Aquaculture 402-403:113-118

*Warburton K (2003) Learning of foraging skills by fish. Fish Fish 4:203-215

Werner E, Mittelbach G, Hall D (1981) The role of foraging profitability and experience in habitat use by the bluegill sunfish. Ecology 62:116-125

Yuen J, Dempster T, Oppedal F, Hvas M (2019) Physiological performance of ballan wrasse (Labrus bergylta) at different temperatures and its implication for cleaner fish usage in salmon aquaculture. Biol Control 135:117-123 